\title{
Contribution of Islamic Banks in Financing Small and Medium Enterprises in the Kingdom of Bahrain
}

\author{
Bashar Matarneh $^{1} \&$ Mousa Almanaseer ${ }^{2}$ \\ ${ }^{1}$ Accounting \& Finance Dept., Applied Science University, Juffair, Kingdom of Bahrain \\ ${ }^{2}$ Banking Finance, Applied Science University, Jufair, Kingdom of Bahrain \\ Correspondence: Mousa Almanaseer, Associate Professor, Banking Finance, Applied Science University, P.O. Box \\ 5055, Juffair, Kingdom of Bahrain. E-mail: mousa_almanaseer@yahoo.com
}

Received: March 4, 2015

Accepted: April 18, 2015

Online Published: June 2, 2015

doi:10.5430/ijfr.v6n3p49

URL: http://dx.doi.org/10.5430/ijfr.v6n3p49

\begin{abstract}
The small and medium enterprises in the Kingdom of Bahrain are of great significance due to their contribution to economic activity; they come after the large companies and no less important, as they absorb large numbers of workers, thus playing a role in reducing unemployment. However, small and medium enterprises encounter difficulties in the funding process especially in obtaining funding for start-ups, especially as commercial banks are sometimes reluctant to fund.

New businesses that are considered high-risk. Thus for these reasons Islamic banks used financing instruments characterized by participation, speculation and cost-plus, through direct cooperation with the government institutions that are responsible for the promotion of small and medium-size enterprise such as the government program known as Tamkeen. The study concluded that the use of Islamic modes of financing contributed significantly to the financing process, which was reflected directly on the Bahraini economy.
\end{abstract}

Keywords: contribution, small and medium enterprises, Islamic banks

\section{Introduction}

Islamic banking has witnessed a remarkable development during the last four decades. This is evidenced by the successes achieved in the GCC, Arab and Islamic countries. This encouraged the Western world to use the principles and instruments of Islamic banking and opened up new channels for financing.

The Islamic banking and finance industry has become a reality in the field of banking and finance as it continues to grow, in terms of the number of businesses and the amount of funds it manages and the diversification of its activities. Despite this development and the successes of Islamic banking and financial enterprises, the experiment with Islamic finance will not be a marginal one; rather, it is a real experiment that has proven its efficiency, flexibility and compatibility throughout the world.

Therefore, the GCC countries have paid more attention in this regard. They took many actions to encourage and fund small and medium enterprises. In this manner, they established the industrial sector, based on the activities of small and medium enterprises for the achievement of sustainable development.

The Kingdom of Bahrain works hard for the diversification of financing for small and medium enterprises because they are important. This is the reason that the Kingdom of Bahrain has included the financing and advancement of enterprises within the government's goals for economic development.

\subsection{Study Problem}

Small and medium enterprises recently began to occupy an important place in the economy of both developing and developed countries. The importance of the research indicated the extent of the contribution of Islamic banks in the financing of such enterprises, as they are regarded to be a key sector of the Bahraini economy for the provision of employment for qualified staff and the increase in the production capacity of Bahrain in order to achieve a more balanced economy by diversifying sources of income for the Kingdom instead of relying solely on petroleum.

\subsection{Study Questions}

1. To what extent do Islamic banks contribute in the financing small and medium enterprises? 
2. To what extent do small and medium enterprises contribute to the economy of Bahrain?

\subsection{Study Objectives}

The current study aims at achieving the following objectives:

1. Describing the importance and definition of small and medium enterprises in the Kingdom of Bahrain.

2. Describing the extent of the contribution of Islamic banks in the financing of small and medium enterprises.

3. Describing the extent of the contribution of small and medium enterprises in the national economy of the Kingdom of Bahrain.

\subsection{Study Hypotheses}

The current study deals with the following hypotheses:

1. Hypothesis 1: Islamic banks contribute significantly in financing small and medium enterprises.

2. Hypothesis 2: Small and medium enterprises contribute significantly in in the national economy of the Kingdom of Bahrain.

\section{Theoretical Framework}

\subsection{Definition of Small and Medium Enterprises}

Although there are various definitions for small and medium enterprises, there is no single agreed definition as they differ from country to country, owing to the different legal frameworks of each country. Therefore, it is difficult to determine one precise, universal concept. One of the most important reasons that led to the differences in the concept of small and medium enterprises is as follows: the differences in the levels of development, the vast expansion in information communications and technology, differences in the global economy as well as the penetration of Internet throughout both developed and developing countries. This means that the enterprise that is regarded as small by the European and American standards is regarded as a medium or large enterprise by the developing countries' standards (Beck, TH., and Demirguc-Kunt, A., 2006). Therefore, the Bahraini legislators have adopted their own definition of small and medium enterprises. They are defined as follows: Enterprises that are working with a specific level of capital and a specific level of labor and aim at producing classified products with known specifications as stated in Table 1.

Table 1. Calsifications of enterprises as indicated by Bahraini legislators

\begin{tabular}{lccc}
\hline & Number of employees & $\begin{array}{c}\text { Invested capital (D.B) (Real } \\
\text { Estate Sector) }\end{array}$ & $\begin{array}{c}\text { Rate of annual turnover } \\
\text { (D.B) (all sectors) }\end{array}$ \\
\hline Micro-enterprise & Up to 10 & $000-20,000$ & Up to 100,000 \\
\hline Small enterprise & $\begin{array}{c}11-50 \text { (up to } 100 \text { in the Real } \\
\text { Estate Sector) }\end{array}$ & $20,001-500,000$ & $-100,001-1$ million \\
\hline $\begin{array}{l}\text { Medium } \\
\text { enterprise }\end{array}$ & $\begin{array}{c}51-250 \text { (up to } 400 \text { in the } \\
\text { Real Estate Sector) }\end{array}$ & $500,001-3$ million & 1 million -1.5 million \\
\hline
\end{tabular}

\subsection{Importance of Small and Medium Enterprises}

The importance of small and medium enterprises is stems from the following:

1. Small and medium enterprises serve to reduce unemployment directly as they rely fundamentally on labor.

2. Small and medium enterprises serve to provide new jobs, thus assisting in the distribution of income and discovering new efficiencies.

3. Small and medium enterprises serve to support economic development as they are based mainly on production capacities.

4. The spread of small and medium enterprises, unlike the big companies, contributes to reducing the marginalization of some geographical areas.

\subsection{Features of Small and Medium Enterprises}

1. Ease of establishment given that they do not require large capital or sophisticated technology and they are capable of producing and working in different fields of industrial and economic development. 
2. Provision of jobs with a low investment cost due to the nature of the production technique used, that characterized by labor-intensive, low-capital requirements and the low qualifications required for labor. These enhancing their role in the reduction of the numbers of unemployed persons, who are characterized mostly by low educational and professional levels especially in the developing countries.

3. Exploitation of citizens' savings and investing them in the different fields of economic activity instead of wasting them in consumption.

4. Products of these businesses provide an important part of the needs of local market, thus reducing imports.

5. Provision of foreign currencies through the reduction in imports and contributions to exports in many cases.

\subsection{Difficulties and Challenges Facing Small and Medium Enterprises Financing}

1. The preference by local customers for similar foreign products sometimes for the sake of tradition, simulation or due to their familiarity with them if the use of such foreign commodities reducing the amount of need of local products.

2. These enterprises often depend on self-financing and therefore they must work within the limits of restricted capital.

3. Because these enterprises are classified legally as individual enterprises, it is difficult for them to increase the amount of their capital through the offer of shares on the stock market or the issue of bonds to borrow money.

4. Small and medium enterprises face financing problems due to the hesitation by some commercial banks to grant these enterprises medium-term or long-term credit unless such enterprises provide guarantees.

5. Sometimes, the available financing for these enterprises is regarded as inappropriate for its financing needs due to the short-term period or insufficient amount of credit.

The financing is the spirit of projects and many innovative suggestions and ideas for projects are going begging due to inappropriate financing. No enterprise can succeed without the necessary financing, especially in the initial phases.

\subsection{Concept of Islamic Banks}

Islamic banks became a reality not only in the Islamic world, but rather, throughout the whole world by introducing a revival of outstanding economic. After attempts to obliterate Islamic financing over a period of fourteen centuries, it managed to overcome fear, doubt and the fallacies of impossible or inappropriate application for the economic and non-economic needs of modern transactions today.

Islamic banks are defined by Almanaseer (2014), as a bank that operates in accordance with Shari'ah and is guided by Islamic economics. In particular, Islamic law prohibits the collection and payment of usury (interest) on the bank's loans and deposits. In addition, it prohibits Islamic banks from using or dealing in certain commodities and activities such as pork, alcoholic liquor, gambling and dealing in derivatives. The depositors also share in the profits of the bank according to a predetermined ratio. This is unlike a conventional bank, which borrows funds paying interest on one side of the profit and loss account, and lends funds, charging interest, on the other side (Iqbal et al., 2005).

The Islamic financial system is an integral part of the Islamic economy, which seeks to achieve the worship of God through social and economic justice, and equitable distribution of income as well as preserving individual freedom in the context of social welfare (Chapra, 1985). The main principal of the Islamic financial system can be summarized in the following: prohibition of interest, risk sharing, prohibition of activities with element of uncertainty, prohibition of gambling activities, prohibition of the production and sale of goods and services that are prohibited in Islam, sanctity of contracts, moral dimension and zakah (Almanaseer, 2009).

\subsection{Modes of Funds in Islamic Banks}

The modes of finance in Islamic banks are based on the profit and loss sharing mechanisms. The profitability of the projects is the main determinant of financing, not the creditworthiness of the customers or the collateral as applied by commercial banks. This kind of financing provides a code of economic ethic combining the material and spiritual values for the conduct of its system (Abdul Mannan, 1986).

El-Naggar (1985), argues that the investment policy of Islamic banks must include incentives aimed at motivating the whole population to participate in the process of development. Moreover, it will promote economically profitable investments that have socio-economic benefits for the whole population, such as creating additional jobs, introducing 
new technology, reducing the imbalance of payments by increasing the production and adjusting regional imbalances so far Islamic banks have focused on the following financial instruments:

\subsubsection{Murabaha - Cost-Plus Financing (Linguistically)}

Presley (1988) indicates that this model refers to the intermediation of a bank in the purchase of a commodity upon the request of a customer, and then selling this commodity to the customer on deferred payment terms for a price equivalent to the total cost of purchase plus a fixed profit agreed upon by both the bank and the customer. These cover the purchase price and the delivery costs in addition to an agreed-upon amount of profit.The jurists classified Murabaha as trust sales because the seller is entrusted with the information from the purchaser on the purchase price.Murabaha is most widely used for short-term financing and accounts for around $70 \%$ of all Islamic financial transactions (Al-Jarhi et al., 2001).

\subsubsection{Ijarah (Leasing)}

There are two kinds of leasing used by Islamic banks, the operational leasing (Ijarah) and the financial leasing. Using operational leasing Islamic banks have the different machines, equipment and property and then they hire them out to people for the fulfilment of their needs for a fixed, regular payment over an agreed period of time. On the other hand, using financial leasing (Ijarah athumma al-bai) or hire-purchase, there are two contracts involved in this concept. The first contract, Ijarah contract (leasing/renting) and the second contract, Bai' contract (purchase) are undertaken one after the other (Presley, 1988). For example, in a car financing facility, a customer enters into the first contract and leases the car from the owner (bank) at an agreed rental over a specific period. When the lease period expires, the second contract comes into effect, which enables the customer to purchase the car at an agreed price. Ijarah is a popular Islamic instrument and it is most widely used in corporate financing (Al-Manaseer, 2009). Leasing financing has widely been used in Western institutions, but there are significant differences between Islamic leasing contracts based on Ijarah and conventional leasing. Under Islamic law, it is necessary for management, maintenance and insurance of the leased assets to be the responsibility of the leasor, while under conventional leasing contracts these matters are usually the responsibility of the lessee (Wilson, 1997).

\subsection{Mudharaba (Common Speculation)}

This is an arrangement or agreement between a capital provider and an entrepreneur, whereby the entrepreneur can mobilise funds for a business activity. The word Mudharaba is derived from the (Dharba in Ard) or (the quest in the world), that is, the travel for trading. In Islamic jurisprudence, it is based on the principle that the capital shall be provided by one partner (rabb-ul-mal) and the work shall be provided by another man (mudarib) provided. Any profits made will be shared between the capital provider and the entrepreneur according to the ratio that they agree upon at the time of the contract.

However, although both parties share in the profits, only the capital provider bears all of the residual losses if the entrepreneur failsunless the loss has resulted by negligence from the entrepreneur. In this case, the entrepreneur has to bear the loss. Profit-sharing continues until the capital is repaid. Mudarabah contracts take two forms, restricted mudarabah where the contract is in a particular business, and unrestricted mudarabah, where the mudarb is authorized to invest in any business he deems fit (Al-Manaseer, 2014).

\subsection{Bai Al-Salam (Advance Payment for Goods)}

Aslama means to lend, that is, payment presented and delivered in advance. In Al-Salam the sale involves the payment of the full cost in advance and the deferral of the delivery of the specified commodity to a specific time in the future. It is a kind of sales in which the delivery of the goods is deferred and the delivery of the payment is in advance. It's defined as deferred sales with an urgent price. The Bai Al-Salam contract is such as a form of forward sale and is characterized by higher risks so that each party has its own rights in the execution of the contract in the same way as for cash sales. This contrasts with deferred sales, where the goods are delivered in advance and the payment of the sales price is delayed (Al-Manaseer, 2009).

What is deferred in the Bai Al-Salam is the delivery of the commodity purchased. Therefore, it is required for it to be describedin very accurate, detailed specifications in order to avoid disputes after delivery of the goods. The contract is called Salam as the payment of the sales price around which the contract is concluded is called, Salaf or loan. In order to remain within the framework of financial intermediation without committing itself to the work of the traders, the bank can enter into a parallel salam contract in which the bank will be the seller to another party who needs the crops (Rameswurlall, 2005). 


\subsection{Istisna'a (Construction and Manufacturing Financing)}

Istisna'a is an agreement wherein a customer requiring a commodity with clear specifications to be manufactured or developed approaches the bank for financing. The bank offers to have the said commodity manufactured or developed, for him and then, after adding its profit margin, sell it to him. The customer can later pay the price either in lump sum or in installments. This contract has a popular use in the construction sector, where the client seeks financing for his construction project.

Under this contract, the bank undertakes to complete the depicted product during a pre-determined period, while the person requesting the product is obliged to pay the price if it satisfies the terms and description of the depicted product. It is worth noting that the bank is not obliged to carry out the work itself, whereby it can enter into another contract for manufacturing the same product with another manufacturer and set a specific predetermined price with the original client in a way that the bank can make a reasonable profit. However, the bank be held responsible for the construction to match the specification (Al-Jarhi et al., 2001).

\subsubsection{Musharakah (Active Partnership)}

Musharakah or shirkah can be defined as a form of partnership where two or more persons combine either their capital or labour together, to share the profits, enjoying similar rights and liabilities. This concept is normally applied to business partnerships, or joint ventures and is fairly similar to mudarabah financing, except that both the financier and the enterpreneur, take an equity stake in the venture. Therefore, the bank as well as the customer has a stake in the equity capital, and either of them can only be liable for losses amounting to the contributed capital (Lewis et al., 2001).

Musharakah is widely used for joint venture investments. It is also used by Islamic banks for the purchase of real estate, equivalent to a traditional bank mortgage but instead of interest, the Islamic bank receives a share of the rent of the property. There is an important kind of musharakah known as Musharakah Motanaqesa (Diminishing Partnership) this is a contract between a financier (the bank) and a beneficiary. The two agree to enter into a partnership to own an asset. The financier will gradually sell his share to the beneficiary at an agreed price and in accordance with an agreed schedule.

\subsubsection{Tamkeen}

Tamkeen, which means "empowerment", was established on August 2006 as a national reform initiative of the Bahrain Economic Vision 2030. Its main mission is the development of the private sector in the Kingdom of Bahrain in order for it to play the role of the key driver of economic development.

Tamkeen aims at the achievement of two key objectives: 1) fostering the creation and development of enterprises, and 2) providing support to enhance the productivity and growth of enterprises and individuals. Under these objectives are a number of mechanisms and programs that ensure the achievement of such objectives. They have been set based on extensive studies for the determination of gaps found in the labor market at the level of individuals and enterprises and methods of treatment.

Tamkeen intends to launch over 20 new initiatives. These initiatives range from training programs for the development of human resources- whether students, employees, employers or job seekers- with the skills acquired in conformity with the market needs and other qualitative programs for the enhancement of the productivity of individuals and enterprises through the enlightenment and awareness of success factors in the private sector. This is in addition to other programs designed for the development of enterprises whether by providing high quality consulting services to enhance the performance of enterprises or by providing bridge financing to complete the operating capital of enterprises and a number of the other national projects aiming at the enhancement of investment in Bahrain. Tamkeen play a significant an intermediary role in getting finance for small and medium size enterprises from both Islamic and commercial banks.

\section{Study Sample and Methodology}

The study population consist of all funds gave by Islamic banks to the small and medium enterprise, as these information are not available except the funds provided through Tamkeen, we will concentrate on the Islamic funds gave to the small and medium enterprises through Tamkeen as an intermediary between banks and small and medium enterprise. This study adopted the descriptive analytical methodology to show the role of Islamic banking in financing the small and medium enterprises in the Kingdom of Bahrain during 2010 until 2012.

It depended on secondary data from previous resources, books, references and literature in the subject, in addition to analyzing the data submitted by Tamkeen. The study also sought to know the role of small and medium enterprises on the economic development of Bahrain. 


\section{Analysis of the Results and Conclusion}

Table 2. Amount of funding for small and medium enterprises through Tamkeen in 2010

\begin{tabular}{ccc}
\hline Amount of Islamic funding in million USD & $\begin{array}{c}\text { Amount of commercial } \\
\text { funding in million USD }\end{array}$ & $\begin{array}{c}\text { Total Amount of } \\
\text { funding in million USD }\end{array}$ \\
\hline Zero & 17 & 17 \\
\hline
\end{tabular}

We find from Table 2 that the amount of funding for the small and medium enterprises is 17 million USD as most of the funding was from the commercial banks. There are five support programs for small and medium enterprises including business development (istishara), quality management (jawda), growth assistance (tarweej), technical assistance (techania) and marketing assistance (tasweeq). The table indicates that in 2010 there was no funding provided by the Islamic banks in the Kingdom of Bahrain, which are very numerous and are included among the main operating banks.

Table 3. Amount of funding for small and medium enterprises through Tamkeen in 2011

\begin{tabular}{ccc}
\hline Amount of Islamic funding in million USD & $\begin{array}{c}\text { Amount of commercial } \\
\text { funding in million USD }\end{array}$ & $\begin{array}{c}\text { Total Amount of } \\
\text { funding in million USD }\end{array}$ \\
\hline 10 & 14 & 24 \\
\hline
\end{tabular}

We see from Table 3 that the total amount of funding for small and medium enterprises through Tamkeen reached 24 million USD in $2011,42 \%$ of it was provided by Islamic banks and $58 \%$ of it was provided by commercial banks. Therefore, we note that the total amount of funding for small and medium enterprises increased by $70 \%$ compared to 2010 .

Table 4. Amount of funding for small and medium enterprises through Tamkeen in 2012

\begin{tabular}{ccc}
\hline Amount of Islamic funding & $\begin{array}{l}\text { Amount of commercial } \\
\text { funding in million USD }\end{array}$ & Total Amount of funding in million USD \\
\hline $\mathbf{3 0}$ & 16 & 46 \\
\hline
\end{tabular}

We see from Table 4 that the total amount of funding for the small and medium enterprises through Tamkeen reached 46 million USD in 2012, 65\% of it was provided by Islamic banks, while only $35 \%$ of it was provided by commercial banks. It is worth mentioning that while the increase in total funds to small and medium enterprises through Tamkeen in 2012 was 92\%, the increase in Islamic funds was 200\% compared to 2011.

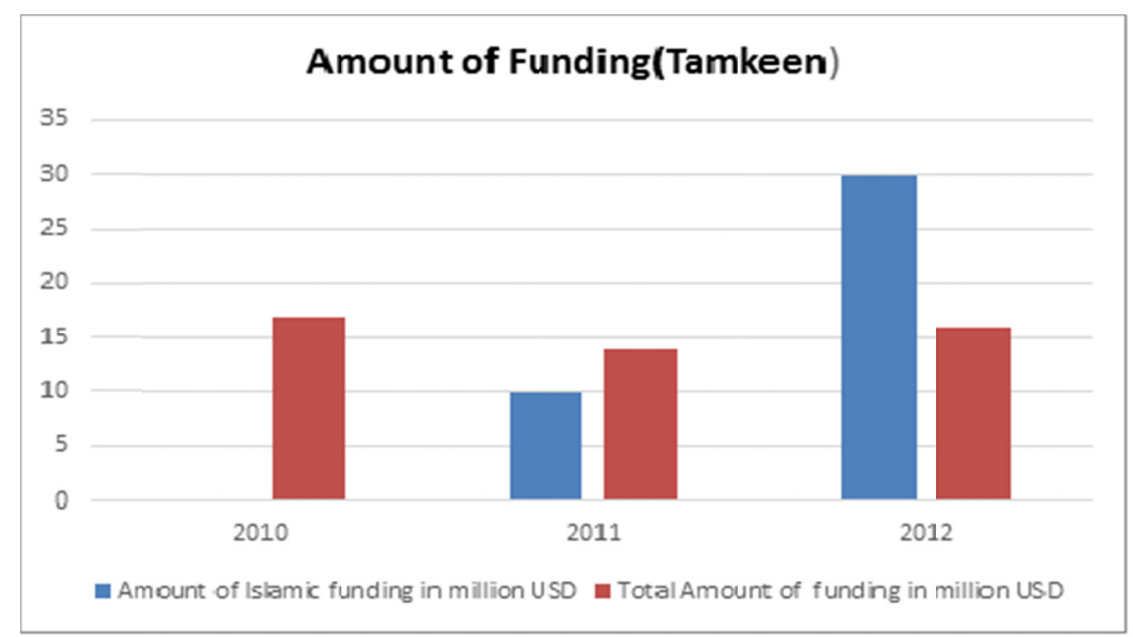

Figure 1. The contribution of Islmic funding for small and medium enterprises in the total funding provided by Tamkeen 
From Figure 1 for the period 2010-2012, we find that in 2010 the Islamic Banks did not contribute any funding for small and medium enterprises in Bahrain through Tamkeen as the total funding provided by Tamkeen was 17 million USD all of it provided by commercial banks. The turning point came in 2011 when the Bahrain Islamic Bank signed an agreement with Tamkeen for an amount of 10 million USD. This reflected in turn upon the significant contribution by Tamkeen to the funding process as it increased by $70 \%$. This in turn resulted from the increase in the number of enterprises funded and training programs provided.

In 2012, the contribution of Islamic funding reached 30 million USD reflecting an increase in total funding of $92 \%$ in comparison with 2011. 2012 is regarded a turning point for Tamkeen for the increase of diversification of funding in order to include many enterprises of private and public sectors. Tamkeen funded 1000 enterprises providing 5000 job opportunities in small and medium enterprises. It should be noted that Tamkeen provided $63 \%$ of its funds to business projects for women, contributing to the inclusion of Bahraini woman in the process of promoting productivity, such as sewing enterprises and development of skills. Furthermore, the beneficiaries from the human capital development programs until the end of 2012 reached 56258(Tamkeen, 2012)

\section{Conclusions}

The contribution of Islamic banks in financing small and medium size enterprises increased significantly during 2010-2012. This attributed to the special features of Islamic mode of finance, which concentrate on risk sharing mechanisms.

Small and medium enterprises contribute significantly in the economy of Bahrain especially in offering jobs and reducing unemployment in addition to developing human resources.

\section{Recommendations}

1. There is a need to pay greater attention to small and medium enterprises not only for the funding process but also for the diversification process such as in the training and promotion of staff efficiency.

2. There should be an increasing awareness for the Islamic Banks for their contribution in the funding of small and medium enterprises as they align with the goals of such banks that take the responsibility of contributing to community service.

3. Courses and symposia should be organized to increasing the awareness of citizens on the importance of small and medium enterprises.

4. There is a need for legislation and regulations to be passed by the Parliament of Bahrain to encourage investment in such enterprises and to provide incentives for the Islamic banks.

\section{References}

Abdul Manan, M. (1986). Islamic economics: theory and practice (foundation Of Islamic economics). The Islamic academy, Cambridge.

Al Manaseer, M.F. (2009). Bank Profitability Islamic and Traditional Banks. Saarbrucken. Germany.VDM Verlag Dr. Muller Aktiengesell schaft\& KG.

Al Manaseer, M.F. (2014). The Impact of the Financial Crisis on the Determinants of the Islamic Banks Profitability - Evidence from GCC. International Journal of Financial Research, 5(3).

Al-Jarhi, M., \& Iqbal, M. (2001). Islamic banking: answers to some frequently asked questions.

Beck, T., \& AsliDemirguc, K. (2006). Small and medium-size enterprises: Access to finance as a growth constraint. Journal of Banking \& Finance, 30(11), 2931-2943

Chapra, M.U. (1985). Toward a just monetary system. Leicester.Islamic Foundation.

El-Naggar, A. (1985). Traditionism and Modernism in a General Developing Strategy. The Publication of International Association of Islamic Banks, Cairo.

Iqbal, M., \& Molyneux, P. (2005). Thirty years of Islamic Banking: History, Performance and Prospects. Great Britain: Palgrave Macmillan.

Lewis, K.M., \& Alqaoud, M.L. (2001). Islamic Banking. Cheltenham, UK: Edward Elgar.

Presley, R.J. (1988). Monetary sector in a financial surplus Islamic developing economy: the case Of Saudi Arabia. Journal of Administrative Sciences, King Saud University, 13(1), 17-33.

Rameswurlall, B. (2005). The Mauritius Islamic finance forum-premier event in Islamic finance. Mauritius, Islamic Finance International Conference Centre, 25-26 July, 2005.

Tamkeen. (2012). Tamkeen Annual Report 2012.

Wilson, R. (1997). Islamic Finance. London: Pearson Professional Limited. 